\title{
Growth and nutritional status of adolescents of public education system
}

\author{
Janine Pereira da Silva1, Valmin Ramos da Silva', Patrícia Casagrande Dias de Almeida², \\ Gustavo Carreiro Pinasco ${ }^{2,3}$, Tiago Pina Bernardes ${ }^{4}$, João Guilherme Ribeiro Jordão Sasso ${ }^{4}$, \\ Natanna Siqueira Spalenza ${ }^{4}$, Cláudio Leone ${ }^{3}$, Joel Alves Lamounier ${ }^{5}$
}

DOI:http://dx.doi.org/10.7322/jhgd.127651

\begin{abstract}
Introduction: The prevalence of obesity in children and adults has increased worldwide exponentially over the past two decades, becoming an important issue of global public health.

Objective: To describe the growth and nutritional status of adolescents of public schools.

Methods: Epidemiological, cross-sectional study, a representative sample of students aged 10 to 14 years of the public schools of the Metropolitan Region of Grande Vitória (MRGV), State of Espírito Santo, Brazil. Data on gender, age, skin colour/race, pubertal stage, socioeconomic class, weight and height were obtained. In the nutritional evaluation, the Height/Age (H/A) and Body Mass Index/Age (BMI/A) indexes, in z-score, of the WHO reference (2007) were considered. For statistical analysis, we used the Qui-square test and Student's t test (Mann-Whitney test for non-normal distribution), and significance level of $p<0.05$. Study approved by the Institutional Research Ethics Committee.
\end{abstract}

Results: There were assessed 818 adolescents, with average age of $12.8 \pm 1.1$ years, female predominance $(58.3 \%)$, mixed skin colour/race $(41.7 \%)$, post-pubertal stage $(53,4 \%)$ and socioeconomic class C (59.5\%). It was identified very low stature in $0.4 \%$ and low stature in $1.8 \%$ of adolescents. Overweight was diagnosed in $227(27.7 \%)$ students, represented by overweight (18.7\%), obesity $(8.4 \%)$ and severe obesity $(0.6 \%)$; While $0.2 \%$ presented severe thinness and $2.7 \%$ thinness. The mean z-score of girls' height $(p=0.024)$ was higher than the WHO reference, as well as the BMI $z$-score of girls $(p=0.0001)$ and boys $(p=0.0002)$.

Conclusion: Adolescents of public schools of MRGV achieve adequate growth, even higher, on average, proposed by WHO (2007). However, they also present a high prevalence of overweight, indicating that the region is at an advanced stage of nutritional transition.

Keywords: growth, nutritional status, adolescent, nutritional transition.

\section{INTRODUCTION}

The prevalence of obesity in children and adults has increased exponentially over the past two decades, becoming an important issue of global public health ${ }^{1}$. In this sense, the association of obesity with chronic noncommunicable diseases is also concerned as this may lead to an increase in cardiovascular risk and metabolic syndrome in the early stages of life, resulting in substantial risks for alterations in glycolipid metabolism, arterial

\footnotetext{
1 Mestrado em Políticas Públicas e Desenvolvimento Local. Escola Superior de Ciências da Santa Casa de Misericórdia de Vitória (EMESCAM) - Vitória (ES), Brasil.

2 Departamento de Pediatria. Escola Superior de Ciências da Santa Casa de Misericórdia de Vitória (EMESCAM) - Vitória (ES), Brasil.

3 Laboratório de Delineamento de Estudos e Escrita Científica. Departamento de Saúde da Coletividade. Faculdade de Medicina do ABC (FMABC) - Santo André (SP), Brasil.

4 Graduando em Medicina. Escola Superior de Ciências da Santa Casa de Misericórdia de Vitória (EMESCAM) - Vitória (ES), Brasil.

5 Departamento de Pediatria. Universidade Federal São João Del Rey (UFSJ) - São João Del Rey (MG), Brasil. Corresponding author: Janine Pereira da Silva - E-mail: janine.silva@emescam.br

Trabalho baseado na tese intitulada "Prevalência de excesso de peso e sua associação com os fatores de risco cardiovascular e síndrome metabólica em adolescentes da rede pública estadual de ensino da Região Metropolitana da Grande Vitória - ES”, apresentada por Janine Pereira da Silva ao Programa de Pós-Graduação em Ciências da Saúde, Área de Concentração em Saúde da Criança e do Adolescente, da Faculdade de Medicina da Universidade Federal de Minas Gerais (UFMG), em 2014.
}

Suggested citation: Silva JP, Silva VR, Almeida PCD, Pinasco GS, Bernardes TP, Sasso JGRJ, et al. Growth and nutritional status of adolescents of public education system. J Hum Growth Dev. 2017; 7(1): 42-48. DOI:http://dx.doi.org/10.7322/jhgd.127651 Manuscript submitted in 2016, accepted for publication in Sep 2016. 
hypertension, diabetes mellitus type 2 and premature cardiovascular disease $\mathrm{e}^{2-4}$.

The rapidity as these changes are occurring has been attributed to the nutritional transition that is characterized by recent changes in lifestyle and food patterns of the population, resulting from industrialization, urbanization, economic development, and globalization. In general, this process is characterized by the almost absence of severe energy-protein malnutrition, presence of short stature (possible sequel of chronic malnutrition in the first years of life) and by the increase of overweight and obesity at alarming population scales, which progressively reach the lower socioeconomic strata ${ }^{5}$.

Brazil, following the world trend, has shown significant increase in the prevalence of overweight and obesity in the last four decades, including the young population $^{6}$, however, their values are not well defined by state or metropolitan areas, especially among younger adolescents, because of the limited number of population studies in this age group. National studies have shown a high prevalence of overweight in adolescents, varying between $15.3 \%$ and $30.6 \%$, with a reduction in the prevalence of short stature, but in general, they evaluate different populations and not always with the same criteria and diagnoses $^{7-10}$. Thus, the objective of this study is to describe the growth and nutritional status of school adolescents.

\section{METHODS}

This is a cross-sectional, epidemiological study in a probabilistic and representative sample of the population, consisting of adolescents between 10 and 14 years of age, of both genders, attending public schools located in an urban area of the Metropolitan Region of Grande Vitória (MRGV), Espírito Santo State, Brazil, carried out in the period of August 2012 and October 2013. The MRGV is composed of the municipalities of Cariacica, Fundão, Guarapari, Serra, Viana, Vila Velha and Vitória, with 48\% of the total population of the state, with a population of $3,514,952$ inhabitants, with urbanization rate of $98.3 \%{ }^{11}$.

The sample size calculation was based on error margin of $3 \%$, confidence interval of $95 \%$ and overweight prevalence of $20 \%{ }^{6}$. The sample size of 822 subjects was calculated from the equation proposed by Triola ${ }^{12}$, having as reference 27,787 adolescents matriculated in $5^{\text {th }}$ to the 8th grades in the public schools of MRGV, Espírito Santo, Brazil ${ }^{13}$.

The adolescents were selected by random sampling, stratified by conglomerates of unequal sizes, in two stages, with the school being the primary unit and the school class the secondary unit. Inclusion criteria was as follows Students aged 10 to 14 years with no physical disability to interfere anthropometric evaluation, with no secondary obesity, acute or chronic inflammatory diseases or corticosteroid and/or anti-inflammatory use.

The weight of the adolescents (barefoot and wearing light clothes) was obtained using a portable electronic scale Tanita ${ }^{\circledR}$ A-080 (Arlington Heights, Illinois, USA) with a maximum capacity of $150 \mathrm{~kg}$ and graduation of $100 \mathrm{~g}$. Height was measured with a portable stadiometer
Alturaexata $^{\circledR}$ (Belo Horizonte, Minas Gerais, Brazil), with maximum length of $214 \mathrm{~cm}$ and precision of $1 \mathrm{~mm}$. The procedures for obtaining the anthropometric measurements were performed as recommended by the World Health Organization $^{14}$. For the nutritional status were considered the body mass index for age (BMI/A) and height for age (H/A), z-score, the reference of the $\mathrm{WHO}^{15}$, using the $\mathrm{WHO}$ software AnthroPlus version 1.0. $3^{16}$.

The self-assessment of sexual maturation was applied showing the participants specific frames for sex (breasts and pubic hair for girls, genitals and pubic hair for boys) of different pubertal stages of Tanner ${ }^{17}$, the individual had to indicate his current stage of sexual maturation.

Socioeconomic data were obtained considering the Economic Classification Standard Criteria Brazil ${ }^{18}$ through a scoring system associated with the consumption capacity of a household and cut offs of socioeconomic classes segmentation (A1, A2, B1, B2, C1, C2, D, E), also it was used the classification system proposed by $\mathrm{IBGE}^{19}$, employs five categories of "colour" or "race" (white, black, yellow, brown or indigenous).

For statistical analysis, we used comparisons and/or associations with Qui-square test $\left(x^{2}\right)$ and Student's $t$ test (Mann-Whitney test for non-normal distribution). Significance was set at $p<0.05$. This study was approved by the Research Ethics Committee of the Federal University of Minas Gerais (protocol CAAE 0301.0.203.000-11) and the Hospital Nossa Senhora da Glória de Vitória (Protocol 41/2012).

\section{RESULTS}

Out of 822 eligible adolescents, a total of 818 answered (99.5\%), from 13 schools of the public school system of MRGV, Espírito Santo, Brazil. The mean age of the sample was $12.8 \pm 1.1$ years (median of 12.9 years and range of 10 to 14.9 years), with a predominance of females (58.3\%). Demographic variables and growth and nutritional status ratings are presented in Tables 1 and 2, respectively.

Overall, the adolescents had an average H/A $\mathrm{z}$-score of 0.092 , higher than the mean of reference $(\mathrm{p}=$ 0.0121 ) and an average z-score of BMI of 0.2821 , also above the value of reference $(p<0.0001)$.

Figures 1 and 2 show that the $\mathrm{z}$-score values for height and body mass index of adolescents as a whole, have higher frequencies, compared to the expected value reference of the $\mathrm{WHO}^{15}$, values to the left of the median, this are the highest $\mathrm{z}$ scores.

There was no significant difference in median age and mean $\mathrm{Z}$-score of $\mathrm{H} / \mathrm{A}$ and $\mathrm{BMI} / \mathrm{A}$ between genders (Table 3). It was noted also that the average $\mathrm{z}$-score for $\mathrm{H} / \mathrm{A}$ for girls $(\mathrm{p}=0.024)$ was higher than the WHO reference ${ }^{15}$ as well as the average $\mathrm{z}$ - score of BMI/A for girls $(p=0.0001)$ and boys $(p=0.0002)$.

\section{DISCUSSION}

The prevalence of very low stature and low stature was, respectively, $0.4 \%$ and $1.8 \%$ (Table 2 ) in a 
Table 1: Distribution of the demographic variables of 818 adolescents, MRGV, Espírito Santo, Brazil, 2014

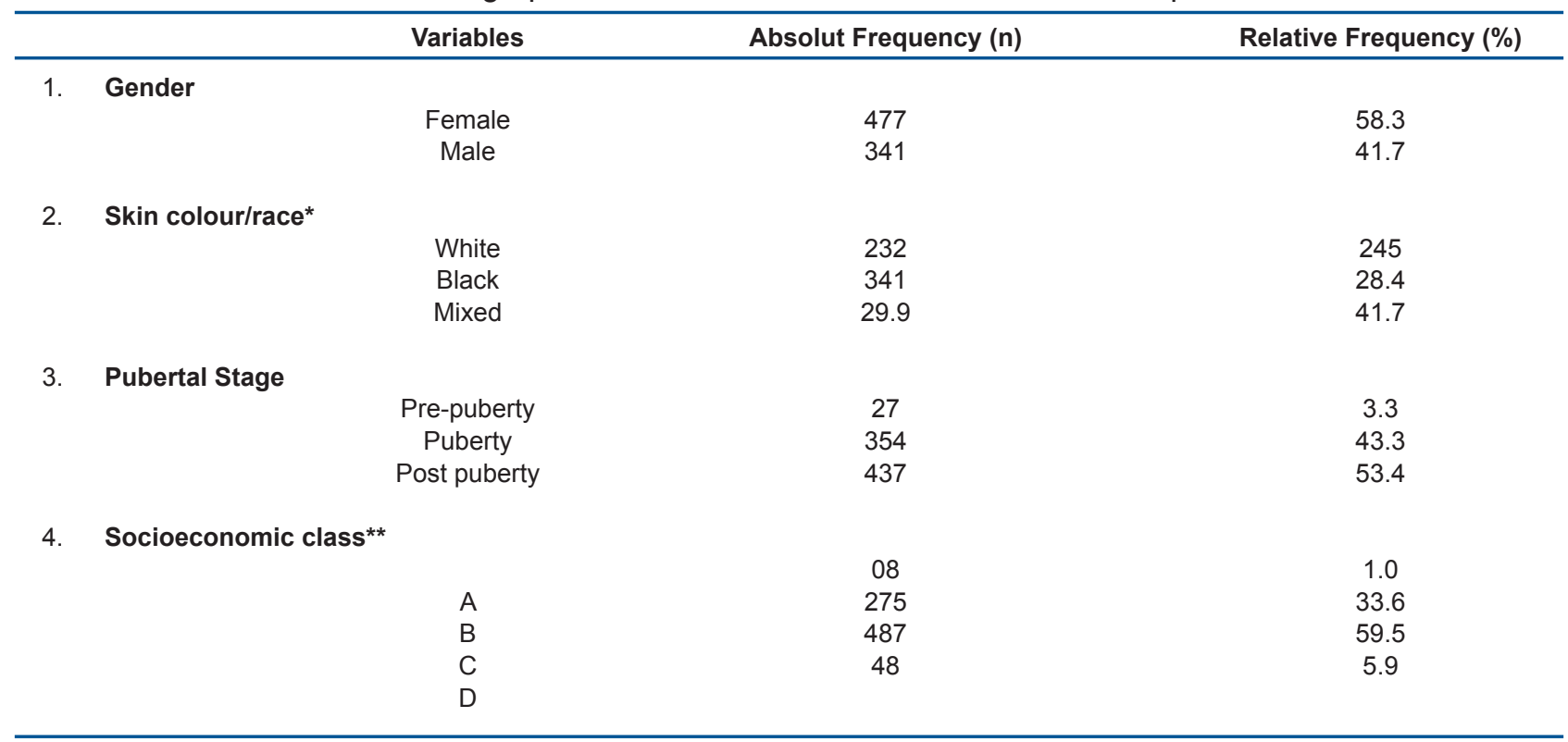

*Unidentified adolescents yellow skin colour or indigenous race; **Unidentified adolescents of the socioeconomic class $\mathrm{E}$.

Table 2: Distribution of adolescents according to growth achieved and nutritional status, MRGV, Espírito Santo, Brazil, 2014

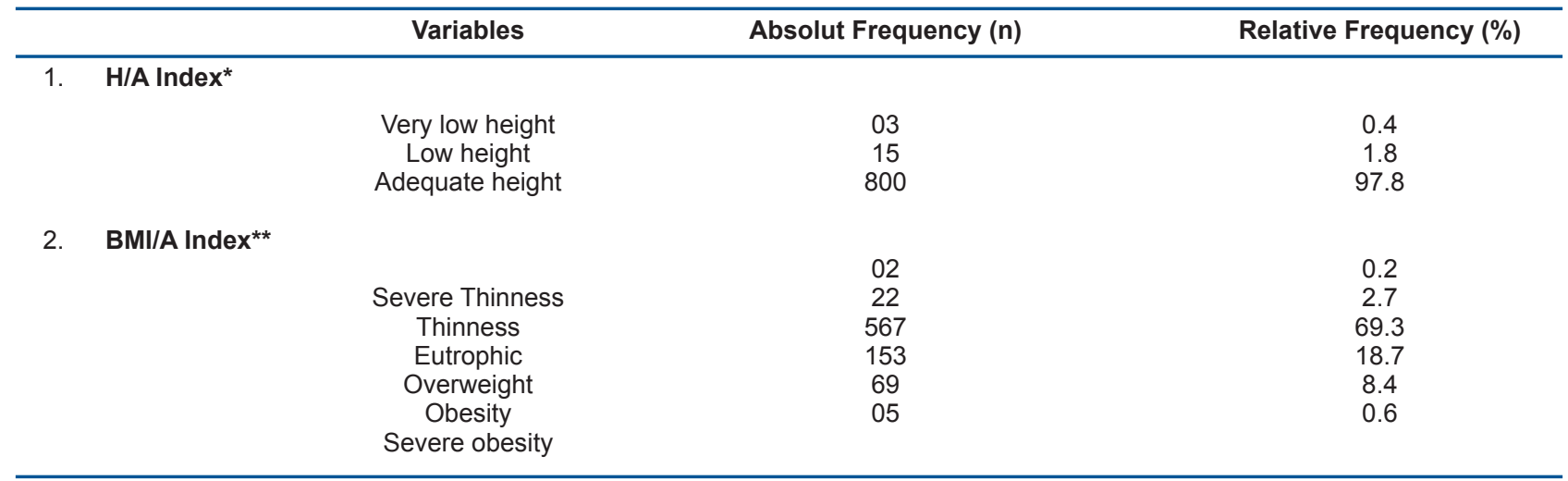

${ }^{*} \mathrm{H} / \mathrm{A}$ : height for age index; ${ }^{*} \mathrm{IMC} / \mathrm{l}$ : body mass index for age index.

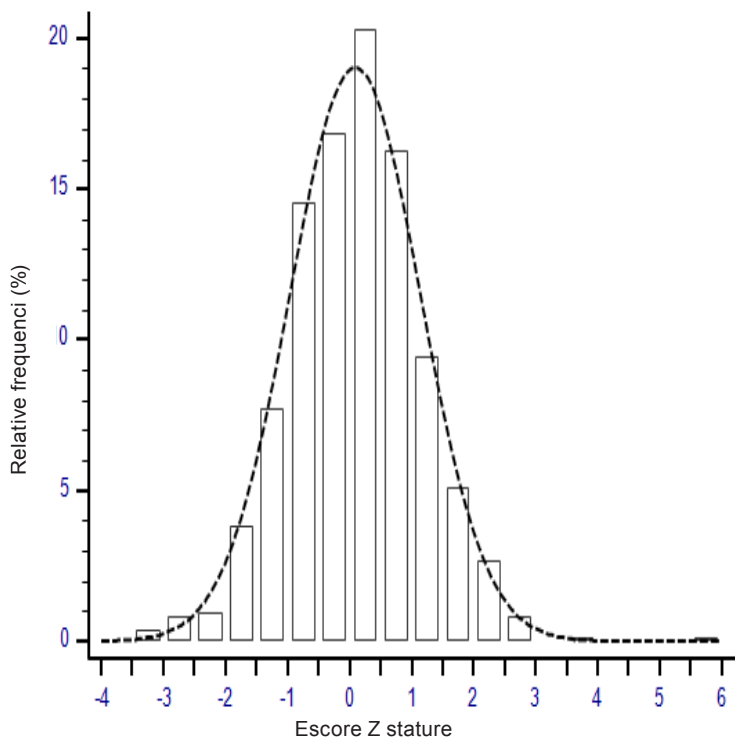

Figure 1: Frequency Distribution curve of the of 818 adolescents according to height-for-age $z$ score,MRGV, Espírito Santo, Brazil, 2014. 


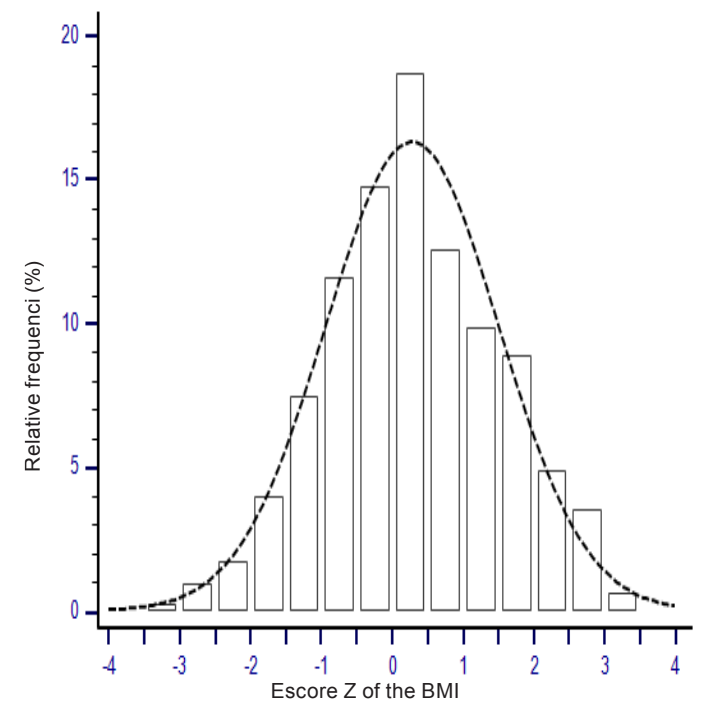

Figure 2: Frequency distribution of the 818 adolescents according to the z-score of the BMI-for-age, MRGV, Espírito Santo, Brazil, 2014.

Table 3: Median of age and Z-score media of height and Z score of BMI of adolescents, according to gender, MRGV, Espírito Santo, Brazil, 2014

\begin{tabular}{lccc}
\hline Variables & Girls $(\mathbf{n}=\mathbf{4 7 7})$ & Boys $(\mathbf{n}=\mathbf{3 7 1})$ & $\mathbf{p}$ \\
\hline Age $^{*}$ in years & $12.9(12.0$ a 13.8) & $12.8(12.6$ a 12.9) & 0.164 \\
Height z-score** $^{*}$ & $0.10( \pm 0.967)$ & $0.08( \pm 1.154)$ & 0.823 \\
BMl z-score $^{* *}$ & $0.30( \pm 1.175)$ & $0.26( \pm 1.285)$ & 0.597 \\
\hline
\end{tabular}

*Median (p25 to p75); **mean ( \pm standard deviation).

probabilistic and representative sample of adolescents, from 10 to 14 years of age, attending public schools of MRGV, Espírito Santo, Brazil. These results show that the young population in the region already reached adequate growth, regardless of the socioeconomic level, since $65.4 \%$ of this population belongs to classes $\mathrm{C}$ and D (Table 1).

The mean of the girls' H/A z-score was 0.10 ( \pm $0.967)$ and the boys' $z$-score was $0.08( \pm 1.154)$, with no significant difference between the genders $(p=0.823)$ (Table 3). The distribution of adolescents, according Z-score of H/A shows that the group, as a whole was over than expected growth, with a median of $\mathrm{H} / \mathrm{A}$ higher values of the $\mathrm{WHO}^{15}$ reference, mainly in females $(\mathrm{p}=0.024)$.

The relevance of these results is that stature growth, especially in developing countries, may represent an advance in the health conditions of children and young people, since it is one of the indicators of quality of life in a country. This secular trend of growth has been observed in some regions of Brazil since the end of the 1990s, and can be interpreted from the perspective of improving the social determinants of health and can also integrate the process of nutritional transition, including outside the major metropolitan areas ${ }^{20}$.

Amorim et al. ${ }^{21}$ evaluated the growth of 13,216 adolescents aged 10 to 18 years, enrolled in the public schools of Paraná, Brazil, and found low prevalence of deficit for the total school by gender, represented by
$1.3 \%$ and $1.4 \%$ higher than the $2.3 \%$ expected in the reference population ${ }^{22}$ for girls and boys, respectively, with normal distribution of the values of $\mathrm{z}$-score $\mathrm{H} / \mathrm{A}$, for both genders $(\mathrm{p}>0.2)$.

In the evaluation of nutritional status, overweight was diagnosed in $227(27.7 \%)$ students, represented by overweight $(18.7 \%)$, obesity $(8.4 \%)$ and severe obesity $(0.6 \%)$ (Table 2$)$. In this study, the prevalence of $27.7 \%$ of overweight is higher than that reported for the country $(25.4 \%)^{6}$ and identified in another study with adolescents from five geographic regions of Brazil $(20.1 \%)^{7}$, but it is below the range observed by Cabrera et al. ${ }^{10}(30.6 \%)$. International studies confirm this result $^{23-25}$, considering criteria for similar nutritional diagnosis.

Globally, the studies report high prevalence of overweight among young populations, with results ranging between $14.7 \%$ and $38.6 \% \%^{7-10,26-29}$. This discrepancy in prevalence can be explained by the use of different criteria for nutritional diagnosis, sample size, broad age range, and social and environmental characteristics of the studied groups, limiting, therefore, the comparison of the results found here.

These data are alarming, since obesity in childhood and adolescence tends to remain in adulthood, and the consequences of overweight are associated with a higher risk of dyslipidemia, insulin resistance, hypertension, cardiovascular diseases, syndromes metabolic and 
maintenance of chronic non-communicable diseases ${ }^{30-31}$.

In the present study, the mean Z-score of BMI/A for girls was $0.30( \pm 1.175)$ and for boys was 0.26 ( \pm 1.285), with no significant difference between the genders $(\mathrm{p}=0.597)$ (Table 3$)$. The distribution of students according to Z-score of BMI/A, shows weight gain than expected, with a median $\mathrm{BMI} / \mathrm{A}$ shifted toward higher values of the WHO reference ${ }^{15}$ in girls $(p=0.0001)$ as in boys $(\mathrm{p}=0.0002)$.

There was a low prevalence of severe thinness $(0.2 \%)$ and thinness $(2.7 \%)$ in this sample, with a rate similar to that reported for the Southeast Region (3.0\%) and lower than the national average $(3.4 \%)^{6}$, thus indicating exiguous frequency current frames of severe protein-energy malnutrition in the adolescent population MRGV, Espírito Santo, Brazil.

Findings show that this region is at an advanced stage of nutritional transition, characterized by changes in lifestyle and dietary patterns of the population, with progressive reduction of physical activity, increased consumption of saturated fats, sugars and refined foods as a consequence of industrialization, urbanization, economic development and globalization. These changes are reflected in nutritional outcomes such as changes in mean height, body composition, morbidity and, in particular, a significant reduction in severe protein-energy malnutrition and short stature, and an increase in the prevalence of overweight and obesity at scales alarming population, which, progressively, also affects the lower socioeconomic strata ${ }^{5}$.

The study presents as a limitation the evaluation of only adolescents frequenting public schools located in urban areas $(93.1 \%$ coverage of schools state-wide public administration $^{13}$ ), which hinders extrapolation of the results to the Brazilian population. However, these findings lead to reflections on the need to be a growth surveillance policy and about the nutritional status, being a periodic and continuous evaluation tool of living conditions, welfare and nutrition of a population ${ }^{32,33}$. In addition, the study presents epidemiological data not yet analysed in the region, which may be useful in the formulation of public policies for the prevention and control of obesity, and also contribute to a rational and less costly reduction of the incidence of chronic non-communicable diseases in adult life.

In conclusion, adolescents of elementary schools of public education system in the Metropolitan Region of Grande Vitória, Espírito Santo, Brazil, have already achieved adequate growth. However, they also present a high prevalence of overweight, diagnosed in $27.7 \%$ of the sample, thus indicating that the young population of the Region is at an advanced stage of nutritional transition.

\section{REFERENCES}

1. Koletzko B, Brands B, Poston L, Godfrey K, Demmelmair H; Early Nutrition Project. Early nutrition programming of long-term health. Proc Nutr Soc. 2012;71(3):371-8. DOI: http://dx.doi.org/10.1017/ S0029665112000596

2. van Vliet M, Heymans MW, von Rosenstiel IA, Brandjes DPM, Beijnen JH, Diamant M. Cardiometabolic risk variables in overweight and obese children: a worldwide comparison. Cardiovasc Diabetol. 2011;10:106. DOI: http://dx.doi.org/10.1186/1475-2840-10-106

3. Musso C, Graffigna M, Soutelo J, Honfi M, Ledesma L, Miksztowicz V et al. Cardiometabolic risk factors as apolipoprotein $\mathrm{B}$, triglyceride/HDL-cholesterol ratio and C-reactive protein, in adolescents with and without obesity: cross-sectional study in middle class suburban children. Pediatr Diabetes. 2011;12(3 Pt 2):229-34. DOI: http://dx.doi.org/10.1111/j.1399-5448.2010.00710

4. Rizzo AC, Goldberg TB, Silva CC, Kurokawa CS, Nunes HR, Corrente JE. Metabolic syndrome risk factors in overweight, obese, and extremely obese Brazilian adolescents. Nutr J. 2013;12:19. DOI: http://dx.doi. org/10.1186/1475-2891-12-19

5. Popkin BM, Gordon-Larsen P. The nutrition transition: worldwide obesity dynamics and their determinants. Int J Obes Relat Metab Disord. 2004;28(Supp.3):S2-9. DOI: http://dx.doi.org/10.1038/sj.ijo.0802804

6. Instituto Brasileiro de Geografia e Estatística (IBGE). Ministério do Planejamento, Orçamento e Gestão (Brasil). Diretoria de Pesquisas. Coordenação de Trabalho e Rendimento. Pesquisa de Orçamento Familiares 2008-2009. Antropometria e estado nutricional de crianças, adolescentes e adultos no Brasil. Rio de Janeiro: IBGE, 2010.

7. Pelegrini A, Silva DAS, Gaya ACA, Petroski EL. Comparison of three criteria for overweight and obesity classification in brazilian adolescents. Nutr J. 2013;12:5. DOI: http://dx.doi.org/10.1186/1475-2891-12-5

8. Conceição-Machado MEP, Silva LR, Santana MLP, Pinto EL, Silva RCR, Moraes LTLP, et al. Hypertriglyceridemic waist phenotype: association with metabolic abnormalities in adolescents. J Pediatr (Rio J). 2013;89(1):56-63. DOI: http://dx.doi.org/10.1016/j.jped.2013.02.009

9. Flores LS, Gaya AR, Petersen RDS, Gaya A. Trends of underweight, overweight, and obesity in Brazilian children and

(Rio J). 2013;89(5):456-61. DOI: http://dx.doi.org/10.1016/j.jped.2013.02.021

adolescents. J Pediatr

10. Cabrera TFC, Correia IFL, Santos DO, Pacagnelli FL, Prado MTA, Silva TD, et al. Análise da prevalência de sobrepeso e obesidade e do nível de atividade física em crianças e adolescentes de uma cidade do sudoeste de São Paulo. J Hum Growth Dev. 2014;24(1):66-71. DOI: http://dx.doi.org/10.7322/jhgd.73455 
11. Instituto Brasileiro de Geografia e Estatística (IBGE). Ministério do Planejamento, Orçamento e Gestão (Brasil). Censo demográfico 2010. Características da população e dos domicílios. Resultados do universo. Rio de Janeiro: IBGE; 2011.

12. Triola MF. Introdução à estatística. 7. ed. Rio de Janeiro: LTC; 2005; p.410 .

13. Ministério da Educação. Instituto Nacional de Estudos e Pesquisas Educacionais Anísio Teixeira (INEP). Censo escolar 2010: visão geral dos principais resultados. Brasília: 2010.

14. World Health Organization (WHO). Physical status: the use and interpretation of anthropometry indicators of nutritional status. Geneva: World Health Organization; 1995.

15. de Onis M, Onyango AW, Borghi E, Siyam A, Nishida C, Siekmann J. Development of a WHO growth reference for school-aged children and adolescents. Bull World Health Organ. 2007;85(9):660-7. DOI: http://dx.doi.org/10.1590/S0042-96862007000900010

16. World Health Organization (WHO). WHO AnthroPlus for personal computers Manual: Software for assessing growth of the world's children and adolescents. Geneva: WHO; 2009.

17. Tanner JM. Growth at adolescence. 2ed. Oxford: Blackwell Scientific Publications, 1962; p. 326.

18. Associação Brasileira de Empresas de Pesquisa (ABEP). Critério Padrão de Classificação Econômica Brasil-2008. ABEP; 2012.

19. Instituto Brasileiro de Geografia e Estatística (IBGE). Ministério do Planejamento, Orçamento e Gestão (Brasil). Características étnico-raciais da população: classificações e identidades. Rio de Janeiro: IBGE; 2008.

20. Nascimento VG, Bertoli CJ, Bertoli LMQ, Feferbaun R, Abreu LC, Leone C. Tendência secular de crescimento de crianças pré-escolares, Brasil, 1997-2007. Rev Bras Cresc Desenvol Hum. 2010;20(2):199-207. DOI: http:// dx.doi.org/10.7322/jhgd.19958

21. Amorim STSP, Rodrigues AGM, Stolarski MC. Estatura de adolescentes matriculados em escolas da rede pública no estado do Paraná, Brasil. Rev Nutr. 2009;22(2):195-205. DOI: http://dx.doi.org/10.1590/S141552732009000200002

22. Kuczmarski RJ, Ogden CL, Guo SS, Grummer-Strawn LM, Flegal KM, Mei Z, et al. 2000 CDC growth charts for the United States: methods and development: Data From the National Health Examination Surveys and the National Health and Nutrition Examination Surveys. Vital Health Stat. 2002;(246):1-190.

23. Kakinami L, Henderson M, Delvin EE, Levy E, O'Loughlin J, Lambert M, et al. Association between different growth curve definitions of overweight and obesity and cardiometabolic risk in children. CMAJ. 2012;184(10):539-50. DOI: http://dx.doi.org/10.1503/cmaj.110797

24. Aounallah-Skhiri H, El Ati J, Traissac P, Romdhane HB, Eymard-Duvernay S, Delpeuch F, et al. Blood pressure and associated factors in a North African adolescent population: a national cross-sectional study in Tunisia. BMC Public Health. 2012;12:98. DOI: http://dx.doi.org/10.1186/1471-2458-12-98

25. Nguyen PVN, Hong TK, Hoang T, Nguyen DT, Robert AR. High prevalence of overweight among adolescents in Ho Chi Minh City, Vietnam. BMC Public Health. 2013;13:141. DOI: http://dx.doi.org/10.1186/14712458-13-141

26. Musa DI, ToriolaAL, Monyeki MA, Lawal B. Prevalence of childhood and adolescent overweight and obesity in Benue State, Nigeria. Trop Med Int Health. 2012;17(11):1369-75. DOI: http://dx.doi.org/10.1111/j.1365-3156.2012.03083

27. Ogden CL, Carroll MD, Kit BK, Flegal KM. Prevalence of Obesity and Trends in Body Mass Index Among US Children and Adolescents, 1999-2010. JAMA. 2012;307(5):483-90. DOI: http://dx.doi.org/10.1001/ jama.2012.40

28. Feferbaum R, Leone C, Nogueira RC, Cavalcanti PN, Cardoso EB, Serra MA. Avaliação antropométrica e por bioimpedância de um programa de educação nutricional para escolares na faixa etária de 7-14 anos durante o período de 10 meses. J Hum Growth and Dev. 2012; 22(3):283-90. DOI: http://dx.doi. org/10.7322/jhgd.46354

29. Sánchez-Cruz JJ, Jiménez-Moleón JJ, Fernández-Quesada F, Sánchez MJ. Prevalence of Child and Youth Obesity in Spain in 2012. Rev Esp Cardiol. 2013;66(5):371-6. DOI: http://dx.doi.org/10.1016/j. rec.2012.10.012

30. Weiss R, Kaufman FR. Metabolic complications of childhood obesity: Identifying and mitigating the risk. Diabetes Care. 2008;31(suppl. 2):S310-16. DOI: http://dx.doi.org/10.2337/dc08-s273

31. O'Malley G, Santoro N, Northrup V, D’Adamo E, Shaw M, Eldrich S, et al. High normal fasting glucose level in obese youth: a marker for insulin resistance and beta cell dysregulation. Diabetologia. 2010;53(6):1199209. DOI: http://dx.doi.org/10.1007/s00125-010-1693-0

32. Leone C. Human growth: parameters and reflections about growth references. J Hum Growth Dev. 2014;24(1):7-10. DOI: http://dx.doi.org/10.7322/jhgd.76138

33. Bezerra IMP, Sorpreso ICE. Concepts and movements in health promotion to guide educational practices. J Hum Growth Dev. 26(1): 11-20. DOI: http://dx.doi.org/10.7322/jhgd.113709 
This article is distributed under the terms of the Creative Commons Attribution 4.0 International License (http://creativecommons.org/licenses/by/4.0/), which permits unrestricted use, distribution, and reproduction in any medium, provided you give appropriate credit to the original author(s) and the source, provide a link to the Creative Commons license, and indicate if changes were made. The Creative Commons Public Domain Dedication waiver (http://creativecommons.org/publicdomain/zero/1.0/) applies to the data made available in this article, unless otherwise stated.

\section{Resumo}

Introdução: A prevalência de obesidade em crianças e adultos tem aumentando de modo exponencial nas últimas duas décadas, configurando-se como importante problema de saúde pública global.

Objetivo: Descrever o crescimento e o estado nutricional de adolescentes frequentadores de escolas públicas.

Método: Estudo epidemiológico, transversal, com amostra representativa de estudantes (dez a 14 anos) da rede pública estadual da Região Metropolitana da Grande Vitória (RMGV), ES, Brasil. Obtidos dados referentes ao sexo, idade, cor/raça, estádio puberal, classe socioeconômica, peso e estatura. $\mathrm{Na}$ avaliação nutricional, foram considerados os índices de estatura para idade (E/I) e índice de massa corporal para idade (IMC/I), em escore z, do referencial da OMS (2007). Para análise estatística, utilizou-se o teste Qui-quadrado e t de Student (Mann-Whitney para distribuição não normal), e nível de significância de $p<0,05$. Estudo aprovado pelo Comitê de Ética em Pesquisa Institucional.

Resultados: Avaliados 818 adolescentes, média de idade da amostra de 12,8 $\pm 1,1$ anos, predomínio do sexo feminino $(58,3 \%)$, cor/raça parda $(41,7 \%)$, estádio pós-púbere $(53,4 \%)$ e classe socioeconômica C $(59,5 \%)$. Identificou-se muito baixa estatura em $0,4 \%$ e baixa estatura em $1,8 \%$ dos adolescentes. 0 excesso de peso foi diagnosticado em $227(27,7 \%)$ estudantes, representado por sobrepeso $(18,7 \%)$, obesidade $(8,4 \%)$ e obesidade grave $(0,6 \%)$; enquanto $0,2 \%$ e $2,7 \%$ deles apresentaram magreza acentuada e magreza, respectivamente. A média do escore $z$ de estatura das meninas $(p=0,024)$ foi superior ao referencial da OMS, assim como a do escore $z$ do IMC das meninas $(p=0,0001)$ e dos meninos $(p=0,0002)$.

Conclusão: Os adolescentes da rede pública estadual da RMGV já alcançam um crescimento adequado, inclusive superior, em média, ao proposto pela OMS (2007). Contudo, também apresentam prevalência elevada de excesso de peso, indicando que a Região está em fase avançada de transição nutricional.

Palavras-chave: crescimento, estado nutricional, adolescente, transição nutricional. 